\title{
VERTICAL INCOME TAX EXTERNALITIES AND FISCAL INTERDEPENDENCE: EVIDENCE FROM THE U.S.
}

\author{
Álex Esteller-Moré ${ }^{\mathrm{a}}$ and Albert Solé-Olléa \\ Departament d'Hisenda Pública \\ Universitat de Barcelona
}

\begin{abstract}
Concurrent taxation is a feature of many federal systems. As a consequence of this fact, the tax policy of one level of government affects the tax base of the other. This paper carries out a theoretical analysis of the interdependent tax-setting decisions of federal and regional governments, paying special attention to institutional features that characterise the U.S. federal system in practice and that formally link the taxes employed at various levels of government (i.e.: tax deductibility). The developed hypotheses are tested with data corresponding to the U.S. personal income taxes for the last decade. We find that when the federal government increases taxes, there is a significant positive response of regional taxes.
\end{abstract}

JEL Classification Numbers: H3, H21, H77

Address: Albert Solé-Ollé (asole @eco.ub.es)

Dpt. D'Hisenda Pública

Facultat de Ciències Econòmiques

Universitat de Barcelona

Av. Diagonal, 690, Torre 4, Pl. $2^{\mathrm{a}}$

08034-Barcelona (SPAIN)

\footnotetext{
${ }^{a}$ We acknowledge financial research support as Consolidated Research Group in „Fiscal Federalism and Regional Economics“, 97SGR-3190898, by the Generalitat de Catalunya, and also from CICYT SEC971202, Ministerio de Educación y Cultura, and thank Loke Yiing Jia for providing part of the data. We are grateful for the comments received from the participants in the Research Seminar of the University of Barcelona; the XXIII Symposium on Economic Analysis (UAB); the Vth Spanish Meeting of Public Economics (University of Oviedo); the 1999 Annual Conference of the Royal Economic Society (University of Nottingham); the $4^{\text {th }}$ Spring Meeting of Young Economists (University of Amsterdam); and the participants in the Workshop "Fiscal Competition and Federalism in Europe", in the ZEW. Especially helpful have been the comments from Antoni Castells.
} 


\section{NON-TECHNICAL SUMMARY}

The main aim of this piece of work is to check the empirical relevance of an economic failure that can arise in a federation. Technically, such problem is so-called "vertical tax externality". It produces when two or more layers of government of the federation share the same tax base. Under those circumstances, and being such tax base distortionary (i.e., responds negatively to increases in the effective tax rate), when one of those layers of governments increases the tax pressure over the tax base there originates a decrease in the revenues of the other layer of government as long as this does not change its tax parameters. However, it is expected that later one (in our model, we suppose immediately), the government that had not varied its tax parameters do it now, in order the combination of fiscal pressure and public goods obtained is optimal again. On the whole, the fiscal decisions of both layers of government are not independent, and in the worst of the worlds, both could end up in the negative slope of the "Laffer curve", that is, the co-ordination of their tax decisions could incite governments to set up tax levels so high that would get negative variation in revenues from that tax rate increases.

We empirically analyse the problem cited above with US data. The institutional setting in that country perfectly fits the conditions required for a "vertical tax externality" to arise. On the one hand, the federal, State and local governments share the income tax, which tax base is distortionary, as has been empirically showed in other studies. We centre our analysis on the fiscal interdependence between the Federal and State government. And, on the other hand, during the period of the study (1987-96) there have been quite important fiscal reforms that allow for variability in the effective federal tax rate, to which according to our theoretical model should follow reactions in the State government's decisions.

From the results of the empirical analysis, we find out that certainly there exists a clear interdependence in the fiscal tax decisions of both layers of governments. In particular, we find that when the federal government increases in one point the effective tax rate in the income tax, the State government do also increase their tax rate, in 0.2 points. However, such results cannot be exclusively attributed to the effect of the "vertical tax externality", but also to the effects of the deduction of the State tax in the Federal tax (depending on the States, such deduction can adopt several forms), though from the empirical analysis, we cannot discern the importance of each one of these effects. 


\section{Introduction}

Traditional literature on fiscal federalism has devoted much interest to the analysis of fiscal externalities that arise among regional governments. Many different investigations have dealt with issues of tax competition, and tax exporting, both theoretically (Gordon (1983), Arnott and Grieson (1984) and Mintz and Tulkens (1986)) and empirically (Stephenson and Hewett (1983), and Case (1993) on the first topic, and Bird and Slack (1983) and Hogan and Shelton (1984) on the second one). There also exist some works analysing the relevance of expenditure spillovers among neighbouring regional governments (Case, et al. (1993)). However - as Keen (1997) has pointed out in a recent survey -, it also has to be recognised the relevance of externalities between levels of government. In a federal setting, characterised by the existence of a federal government and many regional governments, it is quite possible that the policy decisions of one level of government have an effect on the policy outcomes of the other level. If both levels ignore such policy externalities, the resulting decentralised policy decisions could be sub-optimal from a social point of view. Those vertical spillovers can arise both on the expenditure side of the budget (Dahlby and Wilson (1997)), and in tax-setting situations. This paper will deal with this last topic.

Vertical externalities in the design of tax policy arise mainly as a result of concurrent taxation. In many federal countries, some tax bases are joint property of the federal and regional levels of government. That is, both levels of government have the capacity to change fundamental tax parameters of the same base. It has to be stressed that tax-sharing arrangements - that is, when the regional government is entitled to receive a share of the revenues raised in its territorial jurisdiction - do not conform to what we mean by 'concurrent taxation'. Tax-sharing is a necessary but not sufficient condition for our definition of concurrent taxation; what is in fact necessary is that both levels of government share tax powers regarding that base. In that case, the tax rate (or other parameters of the tax that define the tax burden) set by one level of government affects the revenues raised by the other. Of course, for that vertical tax spillover to arise the tax base has to be responsive to tax rate changes; that is, the tax has to be distortionary. In this setting, if each level of government ignores the effects its tax policies have on the revenues of the other level of government, the tax rates will be raised too much, and both may obtain less revenue 
than in the case of co-ordinated decision-making.

The interest of public finance scholars in tax spillovers arising from concurrent taxation is very recent. Traditionally, different authors have pointed out some administrative problems related to the joint property of tax bases. Musgrave (1983), and Break (1984) worried about the higher compliance and administrative costs that such a taxing arrangement among levels of government generates, and Tanzi (1995) and Bordignon et al.(1996) emphasised the moral hazard problems appearing when different levels of governments collect joint taxes. Nevertheless, the first papers dealing with vertical externalities caused by uncoordinated distortionary taxation where those of Flowers (1988) and Johnson (1988). More recently, Wagoner (1995), Wrede (1995), Boadway and Keen (1996), Dalhby (1996), Boadway et al. (1997), and Sato (1997) have also addressed this issue.

Up to now, and to our knowledge, the only article that has tried to quantify the magnitude of the tax interdependence among levels of government is Besley and Rosen (1996). Their analysis deals with spillovers in gasoline and cigarettes tax setting, and uses U.S. data for the period 197589. They find that when the federal government increases its taxes there is a significant response of state taxes, confirming the vertical externality hypothesis. However, we think more empirical analysis of that kind - extending it to other federal countries and other taxes - is needed. In particular, it would be very interesting to have better knowledge about vertical externalities in 'first class' taxes, like the personal income tax. The main purpose of this paper is precisely to perform an empirical test of the existence of vertical externalities in the U.S. personal income tax. In a forthcoming paper, we will analyse that hypothesis for the Canadian case, paying special attention to the interaction between the vertical tax externality and equalisation grants.

Interdependent tax-setting decisions regarding to personal income taxation is actually a relevant field of study in the Spanish case. Nowadays, Spanish regional governments have their own progressive personal income tax. Although the definition of the tax base can not be modified, the Spanish regional governments have the power to change the tax rates and tax credits within some limits ${ }^{1}$. Up to now, regional governments have not used its tax power to modify tax burdens yet.

\footnotetext{
${ }^{1}$ In particular, the reform of the regional financing system in Spain has consisted in splitting the personal
} 
Nevertheless, due to the short life of this tax arrangement, it is perhaps early to derive conclusions about their tax-setting behaviour. Moreover, the reform of personal income taxation currently undergone by the central government will make more likely the reaction by regional governments to the foresighted central income tax burden decreases ${ }^{2}$.

The structure of the paper is as follows: in the next section, we present a simple theoretical model in order to ascertain the sign and magnitude of the responses of each level of government to tax rate changes of the other. This model is developed in sections 2.2 and 2.3 according to the especial institutional situations of the U.S. that will be later used in the empirical analysis. In section 2.5, we perform some simulations based on the theoretical model, and the real situations of the US. In the third section, we test the different hypotheses we find in the theoretical model. Finally, in the fourth section, we propose some extensions to the analysis, and conclude with some relevant comments for the Spanish case.

\section{Theoretical Analysis}

In this part of the paper, our purpose will be the theoretical study of the vertical tax externality. In particular, we want to ascertain the sign and magnitude of the reaction of each level of government to an exogenous tax rate change of the other. In order to carry out this analysis, we have to assume a certain behavioural model of federal and regional tax- setting. However, there is no consensus among the public finance scholars with respect to the most appropriate way to represent the process that generates tax decisions. The most commonly used is the median voter framework, but other politically motivated models, like probabilistic voting models (Dixit and

income tax into two tariffs, $15 \%$ for the regional government, and $85 \%$ for the central government. At the same time, the unconditional grant they previously received has been reduced by the same amount as the standardised revenues coming from the share of the personal income tax. Although, the regional governments have now power to change the tax rates and the amount of the tax credits, the variation in the resulting regional tax liability cannot be higher than $20 \%$. See Ruiz-Huerta, and López-Laborda (1997) for a critical revision of the reform.

${ }^{2}$ The Reform of the personal income tax has not still been approved by the Parliament. In any case, the purpose of reform consists of a reduction of the top marginal tax rate from $56 \%$ to $48-50 \%$, a generalised reduction in the tax burden of all income-classes, and a conversion of the personal tax credits into a tax base deduction. Although any change in the tax base will affect both the central and regional income taxes, it seems that the tax rate reductions will only apply to the central one. See Pedrós (1998) for a survey and comment of the planned reform. 
Londregan (1998)), or rational retrospective voting models (Besley and Case $(1995, \mathrm{a})$ ) could be used. Nevertheless, as a practical device, we employ a simple characterisation of each government objective function; accordingly, we will suppose that each layer of government maximises the indirect utility of a representative agent.

Given that our ultimate aim will be the empirical estimation of the regional response to changes in the federal tax rate in the US, we base the theoretical analysis on the particular institutional structures of that federal system. Apart from the vertical tax externality, in the U.S. there are particular features that link the income taxes of both levels of governments. For instance, taxpayers are able to deduct the state personal income tax from the federal tax base (Tax deductibility). Moreover, in some states they can also deduct the federal income tax from the state tax base (Reciprocal Tax deductibility). As we will see, all these special features will by themselves lead to interdependence in tax setting. Therefore, it will be necessary to isolate in the theoretical analysis the effect of these institutional features from the vertical tax externality itself.

\subsection{The Basic Case}

We assume that both levels of government, the Federal and the Region ${ }^{3}$, co-occupy the same tax base $^{4}$. They both maximise the indirect utility function of a representative agent - which already embodies her maximising behaviour - subject to their respective budget constraints, and taking as given the level of provision of the other layer of government. This fact will precisely provoke the vertical tax externality we want to study. Analytically, the problem for the regional government is the following ${ }^{5}$

\footnotetext{
${ }^{3}$ No without loss of generality, we assume that there is just one regional government. Otherwise, in conjunction with the vertical tax externality, we should also have to take into account the horizontal tax externalities. For a complete analysis of this last problem, see the classical work of Gordon (1983), while for a treatment of both kind of externalities at the same time, see Wrede (1996).

${ }^{4}$ In our model, each layer of government just has one tax instrument. However, in a more general setting, there should be many taxes at their disposal. In that case, there could appear cross-effects due to the reaction of the bases to the tax rates of the other instruments. Note that in order a vertical tax spillover to arise it would no longer be necessary the explicit co-occupancy of tax bases.

${ }^{5}$ In this basic setting, the problem of the Federal government can be analogously solved for $t_{F}$. For that reason, in this case, we just present the results for the regional government.
} 


$$
\begin{array}{cl}
\underset{t_{R}}{\operatorname{Max}} & V\left(1+t_{R}+t_{F}\right)+H(G)+h(g) \\
& \text { s.t. } \quad t_{R} B=g
\end{array}
$$

being the consumer price $q=1+t_{R}+t_{F}$. Its components are the following: $t_{R}$, the regional specific tax rate, $t_{F}$, the federal tax rate, and the producer price that has been normalised to the unity $^{6}$. The rest of components are described as follows: $B$ is the tax base; $g$ is the regional public good; and $G$ is the federal public good. The utility derived from regional and federal public good provision is represented by the functions $h(g)$ and $H(G)$, respectively, which enter in an additively and separable manner into the indirect utility function ${ }^{7}$ and behave in the usual way. We transform the problem into a direct one, once we have introduced the regional budget constraint into the objective function. The first order condition (F.O.C.) is the following,

$$
t_{R}: \quad-B \frac{\partial q}{\partial t_{R}}+\frac{\partial h}{\partial g}\left\{B+t_{R} \frac{\partial B}{\partial q} \frac{\partial q}{\partial t_{R}}\right\}=0
$$

where we have made use of Roy's Identity, $\frac{\partial V}{\partial q}=-B$, since we assume the marginal utility of private income to be equal to one. We also suppose throughout all the paper that $h(g)$ is concave, i.e., $\quad h_{g} \geq 0 \geq h_{g g}$; the partial derivative $\frac{\partial B}{\partial q} \leq 0$, and so define the price elasticity as $\varepsilon \equiv-\frac{\partial B}{\partial q} \frac{q}{B} \geq 0$, which is supposed to be constant along the paper. Substituting this last definition, and rearranging the equation, we get the traditional Samuelson condition of public goods allocation in the presence of distortionary taxation,

\footnotetext{
${ }^{6}$ In fact, given that the producer price is fixed and has been normalised to the unity, ad valorem and specific tax rates are equivalent. Although this assumption is not crucial for the base case, it will certainly prove very useful when analysing the tax deductibility case.

${ }^{7}$ This allows us to abstract from complementarity and substitutability between the tax base and public goods. In the same way, such treatment assumes independence between the federal and regional public goods. This last assumption is important in order to isolate the vertical tax externality effect from vertical spillovers in public consumption [Dahlby and Wilson (1997)].
} 


$$
h_{g}=\frac{1}{1-t_{R} \frac{\varepsilon}{q}} \equiv R M C P F \geq 1
$$

We define the right hand side of the equation as the regional marginal cost of public funds $(R M C P F)$. This indicates the marginal income loss for the representative citizen for each additional unit of revenue the government collects. $R M C P F$ is greater than 1 (the marginal utility of income) as long as $\varepsilon \geq 0$. This F.O.C. has the same structure for the federal government. When there is a marginal change in the federal tax rate, the regional government reacts in order to rebalance expression (2). We differentiate two effects that work in the same direction. The first one is what we call expenditure effect, and acts on the left-hand side of expression (2). The tax base erosion due to the federal tax rate increase requires an increase in the regional tax rate in order maintain public revenues, and so the level of public good provision. This effect is reinforced by the fact that we have assumed that $h(g)$ is concave, and so increases in $g$ are always positively valued, though decreasingly. The second one, which operates on the denominator of the right hand side of expression (2), is the dead-weight loss effect, and implies that the region reacts also increasing its tax rate in order to keep the desired ad valorem tax rate $\frac{t_{R}}{q}$. Analytically, all these effects express as follows,

$$
\frac{h_{g g}}{R M C P F}\left\{\frac{\partial g}{\partial t_{F}} d t_{F}+\frac{\partial g}{\partial t_{R}} d t_{R}\right\}+h_{g}\left\{\frac{\partial R M C P F^{-1}}{\partial t_{F}} d t_{F}+\frac{\partial R M C P F^{-1}}{\partial t_{R}} d t_{R}\right\}=0
$$

where the expenditure effect are the first part of the expression, and the dead-weight loss effect, the second one. Rearranging that equation, and substituting the partial derivatives, we can express the slope of the regional reaction function with respect to the tax rate of the federal government ${ }^{8}$,

\footnotetext{
${ }^{8}$ From now one, the state and federal reactions will be expressed in this way, and so the related effects will be implicitly embodied in the slope of the reaction function.
} 


$$
\frac{d t_{R}}{d t_{F}}=\frac{t_{R} \frac{\varepsilon}{q}\left\{\frac{1}{q}-\frac{B}{R M C P F} \frac{h_{g g}}{h_{g}}\right\}}{\frac{-B}{R M C P F^{2}} \frac{h_{g g}}{h_{g}}+\frac{\varepsilon}{q^{2}}\left(1+t_{F}\right)} \geq 0
$$

which is always positive, since both numerator and denominator are positive ${ }^{9}$. Expression (4) shows the interdependency between the tax rates of both levels of governments owed to the vertical tax externality. Note that if $\varepsilon=0$, there would not be any reaction, $\frac{d t_{R}}{d t_{F}}=0$, since the tax base had not been affected. In consequence, in our model, the existence of the vertical tax externality crucially depends both on the co-occupancy of the same tax base, and also on the distorting nature of the tax. Precisely, an empirical test of the vertical tax externality would consist in testing whether such reaction is significantly different from zero ${ }^{10}$.

The vertical tax externality comes out because of an uncoordinated tax setting behaviour by part of both levels of government. In this decentralised setting, the decision of one level of government to increase/decrease its tax rate does not take into account the correspondent decrease/increase of the other government's revenue. Being this the case, this situation leads to a level of taxation relatively higher in comparison to the level that would be set by two coordinated governments. To show such statement, we find the optimal allocation rule that would be chosen by two co-ordinated layers of government. In order to do this, we maximise the same indirect utility function of the representative agent, subject to the budget constraint of both layers of government, and choosing simultaneously both tax instruments.

\footnotetext{
${ }^{9}$ Note that although we have not developed the federal reaction function, by symmetry can be checked that also its slope will be positive, $\frac{d t_{F}}{d t_{R}} \geq 0$.

${ }^{10}$ The sign we have found crucially depends on the assumption of constant elasticity as Keen (1997) has properly noted. However, in order to test empirically the existence of the vertical tax externality the important point is not the sign of the reaction but the reaction itself.
} 


$$
\begin{array}{ll}
\operatorname{Max} & V\left(1+t_{R}+t_{F}\right)+H(G)+h(g) \\
t_{R}, t_{F} & \\
\text { s.t. } & t_{R} B=g \\
& t_{F} B=G
\end{array}
$$

Deriving, we obtain the F.O.C.

$$
H_{G}=h_{g}=\frac{1}{1-\frac{\varepsilon}{q}\left(t_{R}+t_{F}\right)}=\frac{1}{1-\frac{\varepsilon}{q} \tau} \equiv S M C P F
$$

We will call the right hand side of expression (5) social marginal cost of public funds (SMCPF). As can be easily checked, such expression will be higher than the RMCPF and FMCPF, since $\tau$, the combined tax rate, will always be greater than $t_{R}$ or $t_{F}$. As a result, the combined tax rate in the co-ordinated case will be lower than in the uncoordinated one. The optimal social level of taxation, $\tau^{*}$, is implicitly defined by expression (5). Note that this value will not depend on the particular structure that links the taxes of both levels of government (e.g., the presence of tax deductibility, a features that will be analysed in the next sections). Therefore, in order to determine whether the level of combined taxation arising from a particular institutional tax setting is excessively high, it will always have to be compared with $\tau^{*}$.

\subsection{The Case of Tax deductibility}

In the US, state personal income taxes are deductible when calculating the federal income tax base. Recalling that our tax rates can be considered ad valorem [vid. footnote (6)], the expression of the consumer price redefines as $q \equiv 1+t_{F}+t_{R}\left(1-\lambda t_{F}\right)$, where $\lambda$ is the percentage of state tax deductible ${ }^{11}$. Thus, we can see that an increase in the state tax rate translates only in a net increase of the tax burden $1-\lambda t_{F}$. Given the fact that the net state tax burden is reduced by the introduction of the deductibility, it can be expected that this tax provision creates an incentive to a more intensive use of this source of revenue by the states. Therefore, if the reaction of the state to changes in the federal tax rate is positive - as we have shown in the basic case [expression (4)] -, we would expect the introduction of the tax deductibility to reinforce this reaction. 
Taking into account the new expression of the producer price, the problem of the State government now becomes

$$
\begin{aligned}
& \operatorname{Max} V\left(1+t_{F}+t_{R}\left(1-\lambda t_{F}\right)\right)+H(G)+h(g) \\
& t_{R} \quad \text { s.t. } \quad t_{R} B=g
\end{aligned}
$$

and, for the Federal government, transforms into

$$
\begin{gathered}
\underset{t_{F}}{\operatorname{Max}} V\left(1+t_{F}+t_{R}\left(1-\lambda t_{F}\right)\right)+H(G)+h(g) \\
\quad \text { s.t. } \quad t_{F}\left(1-\lambda t_{R}\right) B=G
\end{gathered}
$$

Therefore, in this case, the problem of both layers of government is no longer symmetric. In particular, what has changed is the federal budget constraint, since now the tax deductibility provokes a revenue loss to the federal government. Now, we just state the F.O.C.'s, derived from each problem

$$
H_{G}=\frac{1}{1-t_{F}\left(1-\lambda t_{R}\right) \frac{\varepsilon}{q}}=\frac{1}{1-t_{F}^{N} \frac{\varepsilon}{q}} \equiv F M C P F
$$

and name $t_{F}^{N} \equiv t_{F}\left(1-\lambda t_{R}\right)$ as the federal net tax rate. For the state government,

$$
h_{g}=\frac{1}{\frac{1}{1-\lambda t_{F}}-t_{R} \frac{\varepsilon}{q}} \equiv R M C P F
$$

Performing comparative static over expressions (6) and (7), we cannot conclude whether the tax equilibrium rates with deductibility will be higher or lower than in the base model. In any case, we can intuitively see how both the effects of the vertical tax externality and the state tax

\footnotetext{
${ }^{11}$ Although $\lambda=1$ in the US case if the taxpayer is an itemiser and 0 in other case, that parameter will be useful to derive comparative statics properties.
} 
deductibility point out in the same direction, that is, to an increase in the tax equilibrium tax rates. First, concerning the regional government, there exists what we call a tax deductibility effect, which tends to decrease the $R M C P F$ by the proportion $1-\lambda t_{F}$, and so to increase $t_{R}$. Second, we detect a dead-weight loss effect, which increases the RMCPF as $t_{R}$ increases, and so stops the increase in $t_{R}$. Third, the expenditure effect makes $t_{R}$ increase, since $h_{g}$ is positive. The story would end up here if the federal government would not react, and the regional equilibrium tax rate in this setting would undoubtedly be greater than in the base case. Otherwise, the contrareaction of the federal government weakens such related positive effects, and could even provoke the regional tax rate to be lower. This contra-reaction can be inferred from expression (6). Now the federal government experiences an expenditure effect, having an incentive to recover part of the revenues lost with the deduction increasing $t_{F}$. However, as it raises the statutory tax rate it also increases the size of that loss because of the increase in the deductibility rate. The federal government also experiences a dead-weight loss effect that increases its FMCPF and makes its tax rate decrease. Thus, the reaction of the federal government may not completely restore the net tax burden to the pre-deductibility level. If this happens, the dead-weight loss effect for the regional government is in fact reduced, and so tends to lower the regional tax rate again making the final effect uncertain.

Nevertheless, we can show a particular case where many these effects vanish. If $\varepsilon=0$ - that is, there is no vertical tax externality - FMCPF $=1$ and $R M C P F=1-\lambda t_{F}$. For the regional government, there is only at work the tax deductibility effect, while the behaviour of the federal government does only modify by an expenditure effect. Thus, on the one hand, the federal government is not affected in the margin by the tax decisions of the regional government. In contrast, the latter is certainly affected, and will see reduced its marginal cost, the greater $\lambda t_{F}{ }^{12}$.

In order to develop a test of the vertical tax externality, we must first develop the slope of the reaction functions. For instance, for the regional government, totally differentiating its F.O.C., we

\footnotetext{
${ }^{12}$ The empirical literature on the effect of the US federal tax deductibility of State taxes implicitly assumes that the only effect at work is the tax deductibility effect. Several studies [e.g., Feldstein and Metcalf (1987), Lindsey (1988)] found a significant statistical effect of deductibility on the use of some state taxes. However, they do not consider that part of this effect may be due to the interdependence caused by the vertical tax externality.
} 
find it is ${ }^{13}$

$$
\frac{d t_{R}}{d t_{F}}=\frac{\left(1-\lambda t_{R}\right) t_{R} \frac{\varepsilon}{q}\left\{\frac{1}{q}-\frac{B}{R M C P F} \frac{h_{g g}}{h_{g}}\right\}+\frac{\lambda}{\left(1-\lambda t_{F}\right)^{2}}}{\left(1-\lambda t_{F}\right) \frac{-B}{R M C P F^{2}} \frac{h_{g g}}{h_{g}}+\frac{\varepsilon}{q^{2}}\left(1+t_{F}\right)} \geq 0
$$

From it, and comparing with expression (4), we can state that the reaction of the regional government will always be greater than in the basic model. The reasoning is the following: on the one hand, in the numerator, pushing up the regional tax response, there appears the tax deductibility effect, $\frac{\lambda}{\left(1-\lambda t_{F}\right)^{2}}$. On the other hand, in the numerator, the first term is multiplied by $\left(1-\lambda t_{R}\right)$, while in the denominator, the first term is multiplied by $\left(1-\lambda t_{F}\right)$. Being in practise that $t_{F} \geq t_{R}$, this second effect does also push the state reaction in the same direction.

\subsection{The Case of Reciprocal Tax Deductibility}

In some US States, the state income tax code also allows the deductibility of the federal income tax when calculating the state tax base ${ }^{14}$. In order to analyse how reciprocal tax deductibility affects the marginal cost this States face will follow Feenberg and Rosen's (1986,a) ${ }^{15}$ calculation of the net tax burden of both levels of government with reciprocal tax deductibility. It is obvious that it is not possible to reciprocally deduct both tax returns acting sequentially. Therefore, we set up a simple system of equations to calculate the tax price. We define $S T$ and $F T$ as the state and federal individual income tax burden, and $\lambda$ as the percentage of deductibility, so we have

$$
S T=B t_{R}-\lambda F T t_{R} \quad \text { and } \quad F T=B t_{F}-\lambda S T t_{F}
$$

\footnotetext{
${ }^{13}$ All the analytical results derived from comparative static are available upon request to the authors.

${ }^{14}$ According to the ACIR (1995), eight States allow their taxpayers to deduct the federal income tax from the regional tax base. These States are Alabama, Iowa, Louisiana, Missouri, Montana, North Dakota, Oklahoma, Oregon, and Utah.

${ }^{15}$ Vid. Feenberg and Rosen (1986,a), page 273.
} 
Solving the system, we obtain the net tax rate for federal and state government, $t_{F}^{N}=\frac{t_{F}\left(1-\lambda t_{R}\right)}{1-\lambda^{2} t_{R} t_{F}}$ and $t_{R}^{N}=\frac{t_{R}\left(1-\lambda t_{F}\right)}{1-\lambda^{2} t_{R} t_{F}}$, and the combined net tax rate, $\tau=\frac{t_{F}+t_{R}\left(1-2 \lambda t_{F}\right)}{1-\lambda^{2} t_{R} t_{F}}$.

The numerator in both net tax rates has the same structure than in the case of the tax base deductibility. However, the denominator picks up second round effects, which are the same for both governments, which makes increase a little bit more the next tax rates ${ }^{16}$. Thus, the reciprocal deductibility changes the tax rates in the way described above, and so the consumer price is now $q=1+\tau$. Bearing this in mind, we can now solve the State problem, which solution will be symmetric to the regional one. Analytically,

$$
\begin{aligned}
& \operatorname{Max} V\left(1+\frac{t_{F}+t_{R}\left(1-2 \lambda t_{F}\right)}{1-\lambda^{2} t_{R} t_{F}}\right)+H(G)+h(g) \\
& t_{R} \\
& \text { s.t. } \quad \frac{t_{R}\left(1-\lambda t_{F}\right)}{1-\lambda^{2} t_{R} t_{F}} B=g
\end{aligned}
$$

Operating on it, we obtain the F.O.C. for the State government

$$
h_{g}=\frac{1}{\frac{1}{1-\lambda t_{F}}-\left[\frac{\left(1-\lambda t_{F}\right) t_{R}}{1-\lambda^{2} t_{F} t_{R}}\right] \frac{\varepsilon}{q}}=\frac{1}{\frac{1}{1-\lambda t_{F}}-t_{R}^{N} \frac{\varepsilon}{q}} \equiv R M C P F
$$

As we can see, expression (9) is characterised in the same way, as before, though now there appears the state net tax rate. Given that F.O.C. (9) is exactly symmetric for the federal government, it is crucial to note that now also the federal government has an incentive to have a higher tax rate because of the tax deductibility effect. This new effect provokes second-round behavioural effects for the state government, reinforcing the tendency to have higher tax rates in comparison with the basic case.

\footnotetext{
${ }^{16}$ As an example, let consider a federal and state statutory tax rate of $40 \%$ and $20 \%$, respectively. Then, if we allow state tax deductibility against the federal income tax base, the resulting federal net tax rate is 0,4 $\mathrm{x}(1-0,2)=0,32$; while in the case of reciprocal tax deductibility, it is $0,32 /(1-0,4 \times 0,2) \approx 0,35$, and the regional net tax rate is now $0,2 /(1-0,4 \times 0,2) \approx 0,22$.
} 
In this case, the comparative static becomes very cumbersome, and it results very difficult to unambiguously sign the effects provoked by the effects we have found. However, in section 2.4, we provide some simulation results that corroborate our guess that both net tax equilibrium rates are higher than in the other two previous cases.

It has also been very difficult to sign the slope of the state government reaction function. Although, the higher federal tax rates in response to the possibility of tax deductibility reinforces the tax deductibility effect over state net tax rates, there exists now another effect at work. From expression (9), we can see that increases in $t_{F}$, through the term $\frac{1-\lambda t_{F}}{1-\lambda^{2} t_{R} t_{F}}$, will make the $R M C P F$ to increase, leading to a higher reduction in $t_{R}$ than in the other cases. In spite of the fact that this effect may not be very pronounced, it could eventually dominate the positive tax deductibility effect for high values both of net tax rates and tax base elasticity ${ }^{17}$; as a result, in that extreme case, the reaction of the net tax rates could be negative. Precisely, in the simulations of section 2.4 , can be checked that in the reaction functions there is a peak at high level of net tax rates

\subsection{Simulation results}

In order to get a clearer picture of the consequences for tax interdependence of the different institutional settings analysed in the previous sections we have carried out some simulations. That will help us to determine the magnitude of the equilibrium tax rates and the slope of the reaction functions of each case.

To perform the simulations, we have made some assumptions. First we have defined the tax base in the following way: $B \equiv q^{-\varepsilon} \cdot{ }^{18}$ Note that when there are no taxes the tax base is normalised to one; that means that the simulated tax base values after the action of the different tax instruments

${ }^{17}$ Note that this term, $\frac{1-\lambda t_{F}}{1-\lambda^{2} t_{R} t_{F}}$, multiplies $t_{R} \frac{\varepsilon}{q}$ in expression (9), and the size of the term increases both with $t_{F}$ and $t_{R}$.

${ }^{18}$ See Appendix 1 for a graphical exposition of the Laffer curve arising from such a specification of the tax base. 
have to understood as percentage changes over the pre-tax base ${ }^{19}$. Second we have defined the marginal utility derived from the federal and regional public goods as $H_{G}=\frac{K_{F}}{G}$ and $h_{g}=\frac{K_{R}}{g}$. $G$ and $g$ are defined from the federal and regional budget constraints, which are different in each case, and $K_{F}$ and $K_{R}$ are constant parameters that have to be found in the calibration procedure. Note that these expressions are consistent with the functional form employed in our theoretical analysis.

Substituting the expressions of $B, H_{G}$, and $h_{g}$ into the F.O.C's derived for each of the cases previously analysed, we get a system of two non-linear equations:

$$
\frac{K_{R}}{g}=R M C P F \quad \text { and } \quad \frac{K_{F}}{G}=F M C P F
$$

This system is calibrated to find $K_{F}$ and $K_{R}$ with the aim of be able to replicate the U.S. average federal and state effective income tax rates. We take as the baseline case the Tax deductibility case, that is really the situation in place in most U.S. states. In 1994, the average state effective income tax rate was 5,684\%, and the average federal effective net income tax rate was $19,595 \%{ }^{20}$. From each of the equations in (13), and assuming $\varepsilon=0,75,{ }^{21}$ we found $K_{F}=0,178$ and $K_{R}=0,045$. Taking these values, we solve the non-linear system of equations ${ }^{22}$ to find $t_{F}$ and $t_{R}$ for different situations that we call: Vertical tax externality (that is the basic case developed in section 2.1), Tax credit ${ }^{23}$, Reciprocal tax deductibility (section 2.3), and finally Lump-sum grant.

\footnotetext{
${ }^{19}$ Although the tax base function we use for the simulation does not derive from a specific consumer utility function, it is consistent with the procedure employed in the theoretical analysis that took that same approach.

${ }^{20}$ Vid. for the states, U.S. Bureau of the Census, State Government Tax Collections by State, and for the federal government, U.S. Internal Revenue Service, Statistics of Income Bulletin; both for 1994.

${ }^{21}$ Feenberg and Feldstein (1995) quote several U.S. studies of tax incentives on labour supply, concluding that the compensated labour supply elasticity is around the unity. They also report values for taxable income elasticity (that additionally include the effects of tax rate on the form of compensation, on deductible expenditures) between 1,04 and 1,48. The value we have selected is more conservative than those proposed by Feldstein $(1995, a)$, because we want to show that it is not necessary to employ very high tax base elasticity values in order the vertical tax externality to arise.

${ }^{22}$ To solve the system of non-linear equations we have employed the Fletcher-Powell algorithm.

${ }^{23}$ Its analytical treatment is again available from the authors upon request.
} 
To perform the simulations for the Tax credit and the Lump-sum grant we have assumed that they cause a federal revenue loss equal to that of the baseline case.

The results of the simulation for the U.S. case are presented in Table I. We present the values of the RMCPF and FMCPF, state, federal and combined net tax rates, income tax revenues, and finally the share of state income tax revenue over total revenue raised from that source. Also, in Appendix 2 we show graphically the reaction functions and the equilibrium tax rates. As expected, the state net tax rate is higher in the Tax credit and Tax deductibiliy cases than in the Vertical tax externality, and is even higher in the Reciprocal tax deductibility case. On the other hand, the federal net tax rate is lower in the first two cases and higher in the Vertical tax externality.

For each of the cases analysed we are able to calculate the slope of the regional reaction function by simple marginally perturbing the regional F.O.C. at the Nash equilibrium tax rate. We show the results for two different values of the tax base elasticity, 0,75 and 1,25. Our guess about the relative magnitude of the reaction in the different cases is confirmed. We can see that effectively

Table I: Simulated equilibrium tax rates under different regimes (USA)

\begin{tabular}{lccccc}
\hline & $\begin{array}{c}\text { Vertical tax } \\
\text { externality }\end{array}$ & $\begin{array}{c}\text { Tax } \\
\text { credit }\end{array}$ & $\begin{array}{c}\text { Tax } \\
\text { deductibility }\end{array}$ & $\begin{array}{c}\text { Reciprocal } \\
\text { tax deductibility }\end{array}$ & $\begin{array}{c}\text { Lump-sum } \\
\text { Grant }\end{array}$ \\
\hline$R M C P F$ & 1.024 & 0.758 & 0.759 & 0.974 & 1.017 \\
$F M C P F$ & 1.161 & 1.150 & 1.150 & 1.651 & 1.169 \\
$t_{R}$ & 4.267 & 5.690 & 5.684 & 6.014 & 3.042 \\
$t_{F}$ & 20.433 & 19.592 & 19.595 & 21.357 & 21.114 \\
$t_{T}$ & 24.700 & 25.282 & 25.244 & 27.372 & 24.186 \\
$R_{R}$ & 3.707 & 5.010 & 5.005 & 5.226 & 2.612 \\
$R_{F}$ & 21.356 & 20.234 & 20.239 & 22.178 & 22.321 \\
$R_{T}$ & 25.063 & 25.244 & 25.244 & 27.404 & 24.933 \\
$R_{R} / R_{T}$ & 14.790 & 19.847 & 19.826 & 19.071 & 10.476 \\
\hline
\end{tabular}

Notes: (1) $R M C P F=$ regional marginal cost of public funds, $F M C P F=$ federal marginal cost of public funds, $t_{R}=$ regional effective net tax rate, $t_{F}=$ federal effective net tax rate, $t_{T}=$ combined regional plus federal effective net tax rate, $R_{R}=$ regional revenues, $R_{F}=$ federal revenues, $R_{T}=$ combined regional plus federal revenues.

the size of the reaction follows this pattern: Reciprocal tax deductibility, Tax deductibility, Tax 
credit, Vertical tax externality and Lump-sum grant, and a hypothetical case without externality (in which the response is zero). Those facts will allow us to develop in the next section some empirically testable hypotheses regarding the relevance of tax-setting interdependence in the context of the U.S. experiences.

Table II: Simulated responses of the regional tax rate to exogenous increases of the federal tax rate

\begin{tabular}{lcc}
\multicolumn{3}{l}{ to exogenous increases of the federal tax rate } \\
\hline & $\varepsilon=0.75$ & $\varepsilon=1.25$ \\
& 0,10 & 0,14 \\
Vertical tax externality & 0,19 & 0,25 \\
Tax credit & 0,26 & 0,37 \\
Tax deductibility & 0,28 & 0,40 \\
Reciprocal Tax deductibility & & \\
\hline
\end{tabular}

Notes: (1) These figures represent net regional tax rate changes in response to an increase of the net federal tax rate of 1 point.

(2) The slope of the reaction function is calculated at the Nash equilibrium

\section{Empirical implementation}

\subsection{Empirical framework}

Our main empirical purpose is to estimate the magnitude of the reaction of regional income tax rates to exogenous changes in federal income tax rates; that is, to estimate the slope of the reaction function of the regional government. We choose as our dependent variable the regional tax rate - and not the federal tax rate - because in practice it is not true that there exists only one regional government. With many regional governments and having to define the same tax laws for the entire federation, the federal government does not react to the tax rate changes of each of the regional governments, but to a weighted sum of all of them. 
We use the effective average tax rate as the definition of our tax variables (we label $t_{R}$ and $t_{F}$ as the net effective average regional and federal income tax rates). Those tax rates are calculated as the ratio of income tax revenue to personal income. That is the so-called fiscal pressure ${ }^{24}$. We have chosen personal income instead of taxable income or a more narrow and legal definition of the tax base to avoid the effects that changes in the definition of the tax base over time and regions have on the tax burden. This procedure is supported by the way income tax reductions are usually carried out; although in many cases the changes in effective tax rates have followed statutory tax changes or changes in deductions and credits, in many others income tax reforms have changed also the definition of tax bases. Therefore, doing the calculation in that way means that we do not accept as accurate, reliable and stable the definition of tax base given by the U.S. federal government or by state governments.

The analysis is carried out for U.S. with data corresponding to the last decade. The comparative statics results derived in section 2 for the specific institutional features of those countries allow us to develop complementary hypothesis to test. In the U.S. setting we expect the reaction to exogenous federal tax rate increases of the states that allow the deductibility of the federal income tax to be higher than the states that do not have that provision in their tax code. In the Canadian case, we expect the reaction of the provincial governments with a lower/higher tax rate than the benchmark average tax rate used for equalisation purposes to be negative/positive. Additionally, we expect the reaction of the provincial governments that do not receive equalisation funds to be positive and higher than that of the provincial governments that receive equalisation funds and do have a tax rate higher than the average.

\footnotetext{
${ }^{24}$ Although this variable is not the best alternative to account for the impact of taxation on the allocation of resources in an economy, it is the best practical solution we have been able to find. Of course effective average marginal tax rates (Seater (1985)) would seem to be a more interesting variable to study, but the problem is that they are not found in usual statistical sources. Some authors have also argued in favour of the use of marginal tax rates computed directly from the statutory tax function (Barro and Sahasakul (1986)), or to use the top marginal tax rate (Tannenwald (1991), and Mullen and Williams (1993)). However, this last approach seems better suited to analyse problems of horizontal fiscal competition. Since the mobility of business and high income taxpayers is affected only by statutory tax differentials, the measure of fiscal competitiveness of the regional government does not have to be affected by its income distribution or the composition of the tax base - as are effective tax rates. Nevertheless, as we are mainly interested in vertical spillovers, we can not employ simple characterisations of the statutory regional tax function.
} 
Vertical spillovers are just one of the factors that influence tax-setting. Tax decisions are carried out within a very complex institutional process that accounts for the preferences of voters, electoral interests of politicians, and economic, institutional and cultural constraints. Many of those influences are correlated with federal effective tax rates, thwarting any direct inference about its effects on regional tax rates. As a result of this, and in order to isolate the effect of tax interdependence, it is necessary to control for all the other relevant variables that affect the regional tax-setting process. We include several groups of control variables:

- Economic resources. Richer populations will demand more regional public goods and, as a consequence, will tolerate higher income taxes; we include personal income per capita $(I n c)$, and personal income per capita squared $\left(I n c^{2}\right)$ to control for this effect. Although richer governments - that is, governments receiving more grants from the federal government - will also spend more, they will return part of the amount received to its citizens; so we expect that income taxes will be lower, the higher the amount of transfers received. To control for this effect, we include the per capita amount of grants received from the federal government (Grant).

- Expenditure needs. Populations with higher shares of potential users of public services and/or higher cost of delivering those services will need higher levels of expenditure and, therefore, will be burdened more heavily through income taxes. We include as explanatory variables the size of two groups of potential intensive service users: the proportion of population over 65 and under $18(\operatorname{Pop}(>65)$ and $\operatorname{Pop}(<18))$; we also introduce as cost variables the size of the population (Pop), its squared $\left(P o p^{2}\right)$, and the density of population (Den).

- Political environment. Although many politically motivated models of public policy generation suggest that parties converge at the same platforms regardless of its ideology ${ }^{25}$, many others suggests that if politicians are policy-motivated and do not only care about winning elections the policies implemented need not be the same. For instance, in the U.S. case, some scholars have suggested that Democrat governors tent

\footnotetext{
${ }^{25}$ See Alesina and Rosenthal (1995), chapter 2, for a survey.
} 
to tax and spend more than their republican counterparts (Besley and Case $\left.(1995, b)^{26}\right)$.

We include a dummy variable that accounts for the ideology of the regional executive (D-ExecD, it takes the value of one if the executive is relatively on the left wing of the political arena), and other two variables that account for the ideology of the upper and lower regional legislative chambers (UpperD and LowerD, which are the proportion of left wing representatives in each chamber).

\subsection{The U.S. case: model specification and results}

We will use a panel of data corresponding to the period 1987-96 to test the tax interdependence hypothesis for the U.S. case. This period is of special interest because it includes a period of reductions in federal effective tax rates (1987-90) as a result of the Tax Reform Act of 1986 (Gouveia and Strauss (1996)) and a period of tax increases in the following years.

Many scholars have written about the effects of TRA86 on State government (e.g.,Gold (1991), Ladd (1993) and Tannenwald (1991)). However, most of their attention has been devoted to the analysis of the impact of the reform on State revenues, derived from formal links between federal and state income taxes. Although in many states the state income tax structure does not conform at all with the federal definition, in many others the tax base employed is the federal Adjusted Gross Income $(A G I)$, or even the federal Taxable Income ( $T I$ - that is, AGI less standard or itemised deductions). Moreover, in some states the income tax is calculated as a surcharge over the federal tax liability $(T L)^{27}$. That means that federal tax reform will affect in a different way those groups of states, also depending on the way that changes have produced. On the one hand,

\footnotetext{
${ }^{26}$ Although there is also empirical evidence that raising taxes has high political costs (in terms of votes lost) regardless of the ideology of the party in government. See Peltzman (1992) for evidence regarding the states in U.S., and Stuart and Landon (1997) for evidence regarding the Canadian provincial governments.

${ }^{27}$ In the US, there are seven States that do not make use of their power to tax individual income. From ACIR (1995), we know these states are Alaska, Florida, Nevada, South Dakota, Texas, Washington, and Wyoming. New Hampshire and Tennessee just make a limited use of it, since only certain interest and dividends are taxed. On the other hand, there were five states which tax did not conform at all with the federal one (New Jersey, Pennsylvania, Alabama, Arkansas, and Mississippi), eight of them use a definition of tax base equal to the federal Taxable Income, three impose a tax surcharge on the federal Tax Liability, while the rest of them use the $A G I$ as tax base.
} 
for the group of states that do not conform at all their income tax with the federal one, there is not any direct impact on revenues collected. On the other hand, for the states that use a tax surcharge, all the changes in the federal effective tax rates (coming from changes in the definition of the tax base, changes in deductions and tax credits, and changes in statutory tax rates) will affect their revenues. The states that use the federal AGI as tax base will be affected only by changes in the definition of Gross income and in the cost of earning income, while for the states that use the TI, their collected revenues will be influenced by changes in federal deductions.

Nevertheless, the wind-fall gains (or losses) arising from this kind of direct effects we have related above must not have any influence on the optimal tax rates derived from our theoretical tax model. This is due to the fact that a government that maximises the utility function of the representative citizen would react to the changes passed by the federal government adopting the necessary legal actions to keep effective tax rates at the optimum. If we checked in the empirical model that the states just take as given the wind-fall gains or losses without any additional legal tax change, that would suggest the existence of some sort of fiscal illusion. However, in some cases it would be difficult to disentangle the passive adjustment from the active reaction due to the vertical tax externality and to tax deductibility. That would happen if both reactions go in the same direction ${ }^{28}$. The only way to test if the reaction is due to economic behaviour or to fiscal illusion is to allow the coefficient of $t_{F}$ to differ among the four groups of states previously defined. If we check that the reaction is similar for all of them we could conclude that the cause is owed to the vertical tax externality, and not to fiscal illusion.

The basic equation employed to test all these hypothesis is the following:

$$
\begin{aligned}
t_{R, i t} & =\alpha_{1}\left(\operatorname{DRec}_{i} \times t_{F, i}\right)+\alpha_{2}\left(\operatorname{DNRec}_{i} \times t_{F, i t}\right) \\
& +\alpha_{3}\left(D N C_{i} \times t_{F, i t}\right)+\alpha_{4}\left(D A G I_{i} t_{F, i t}\right)+\alpha_{5}\left(D T I_{i} t_{F, i t}\right)+\alpha_{6}\left(D T L_{i} \times t_{F, i t}\right)
\end{aligned}
$$

\footnotetext{
${ }^{28}$ For instance, suppose that the federal effective tax rate increases because of a widening of the AGI; a regional government whose tax base is the $A G I$ will see increase also its effective tax rate. If that state government suffers from fiscal illusion, it would not react and the state effective tax rate would increase. But even if the state does not suffer from fiscal illusion, according to our theoretical predictions, it will not have to pass legal tax changes to maintain the optimality of its effective tax rate (remember that the combined effect of the vertical tax externality and tax deductibility imply a higher desired effective tax rate).
} 


$$
\begin{aligned}
& +\alpha_{7} t_{L, i t}+\alpha_{8}\left(\bar{t}_{R, i t} x\left(1-\bar{t}_{F, i t}\right)\right) \\
& +\sum_{k} \alpha_{k} Z_{k, i t}+\alpha_{0, i}+\alpha_{0, t}+\varepsilon_{i t}
\end{aligned}
$$

Where DRec is a dummy variable equal to one if the state tax code allows the deductibility of federal income tax, DNRec is a dummy equal to one is the federal income tax is not deductible from the state tax, $D N C$ is a dummy equal to one if the state tax does not conform at all with the federal tax definition, DAGI is a dummy equal to one if the state base is the AGI,DTI is a dummy equal to one if the state base is the TI, DTL is a dummy equal to one if the state uses a tax surcharge on $T L, Z_{k, i}$ are the control variables defined in the previous section. $t_{L, i t}$ is a variable that reflects the degree of utilisation of the income tax by local governments of the state, and its purpose is to test also whether the tax externality is reinforced in those states where the income tax is joint property of the three layers of government. We expect that the reaction of the state tax rate to increases in the local tax rate will be also positive. The variable $\left(\bar{t}_{R, i t} x\left(1-\bar{t}_{F, i t}\right)\right)$ picks up the effect of horizontal tax competition on the level of state tax rates; $\bar{t}_{R, i t}$ and $\bar{t}_{F, i t}$ are the effective average state and federal tax rates of the whole U.S. The first part attempts to reflect the gross tax differentials among the states ${ }^{29}$, and the second accounts for the fact that the tax deductibility offsets part of these gross differentials; that is, net tax differentials decrease when federal tax rates increase (and then reduce the incentives to move among states) ${ }^{30}$. The subscript $i$ indicates the state, $t$ indicates year and $k$ identifies the control variables. The coefficients $\alpha_{0, i}$ and $\alpha_{0, t}$ represent, respectively, state and time specific effects. The estimation of a fixed effects model by OLSQ will give us consistent estimates of the parameters whenever the state effects are correlated with the explanatory variables included in the equation (Mundlak(1978)). State fixed effects represent specific circumstances of each state that stay relatively constant during the analysed period: characteristic of the local political market, specific differences in the cost of local public or a permanent inflow of revenue from other tax resources. Otherwise, if these were

\footnotetext{
${ }^{29}$ This is only a raw approximation to measure the tax levels of each state potential competitors (see Tannenwald(1991) for a previous use of that measure). To correctly account for tax competition we would have to specify more accurately which states are fiscal alternatives for each other.

${ }^{30}$ The definitions of all the variables and the statistical sources are presented in Table III. The main descriptive statistics are presented in Table IV.
} 
correlated with the variables included in the empirical model, the obtained parameters would be inconsistent (Holtz-Eakin(1986)).

The model is tested using data for the 41 states that have broad-based income tax during the period 1987-96; that the number of observations is 410 (41 x 10). We have estimated both a fixed and a random effects version of the model. However, for the different specifications we have tried, the hypothesis of correlation of the fixed effect with the variables included in the model has been accepted at 99\% confidence level (that is, the Hausman test is overcome, refusing the utilisation of a random coefficient model). For this reason, we only report the result for the fixed effects model. We have also performed the Breusch-Pagan test to check the presence of heteroscedasticity rejecting this possibility in all the cases.

The results of the estimation are displayed in Table V. We present four different econometric specifications. In model 1 we employ do not allow the coefficient of the variable $t_{F}$ to vary by groups of states and we do not include any other variable but the control ones. In model 2 we include also the local tax rate, the interaction between $t_{F}$ and the dummy of Reciprocal tax deductibility, and the horizontal competition variable. In model 3 we include the same variables of model 2 but estimate different slopes for the different groups of states. Finally in model 4, we introduce the interaction variables between the political environment control variables and $t_{F}$.

From the results of the estimation we can confirm some of the hypothesis developed up to now. First, and most important, the sign of the state reaction to federal tax changes is positive and statistically significant (see models 1 and 2). A $1 \%$ point change in the federal effective net tax rate supposes a variation in the state tax rate between 0,20 and $0,25 \%$ points. That high value could include the effects both of the vertical tax externality and of the tax deductibility, but we are not able to isolate one from each other. Note also that the parameter remains stable when estimated separately for each group of states (model 3); that is, the reaction of a state which income tax is not formally linked with the federal tax is exactly the same that the reaction of a state that uses federal definitions at some stage of the calculation of the tax liability. Therefore, we can refuse the fiscal illusion hypothesis. 
Second, the parameter of interaction of the federal tax rate and the dummy for reciprocal tax deductibility is positive but not statistically significant at conventional confidence interval. The size of the coefficient is not very high; but remember that the prediction of the theoretical model was that the reaction would be in that case just slightly higher.

Third, and very important as well, the parameter of the local income tax level variable is also positive, statistically significant, and of a considerable magnitude (models 2, 3 and 4). A 1\% point change in the local tax rate supposes a variation in the state effective tax rate around $0,25 \%$ points. That is, the state effective income tax reacts similarly to increases of other taxes that burden its base, regardless of the level of government that levies them. However, also in this case this parameter embodies both the effect of the vertical tax externality and the effect of the deductibility of local taxes into the state income tax.

Fourth, net state tax differentials seem to have a pronounced impact on state tax-setting decisions (models 2, 3 and 4). That is, a decrease in the net effective tax rate (after the federal offset) of the whole U.S. of $1 \%$ point would make state tax rates decrease by $0,3 \%$ points. This results does not necessarily tell us that tax bases fly among states in response to net tax differentials, but certainly tells us that tax officials think the erosion of tax bases (or in votes) will be high if they do not mimic what everybody else is doing.

Fifth, there is some inconclusive evidence on the possibility of a different reaction depending on the ideology of the party that controls the political institutions of the states. Note from the results of model 4 that the coefficient of $t_{F}$ has decreased but that the coefficient of the variable that interacts $t_{F}$ with a democrat governor or a lower house controlled by democrats is positive and significant (although the second one only at a 90\% confidence level). On the other hand, the effect of an upper house controlled by democrats has a positive but no statistically significant effect on state tax reactions to federal tax changes. In any case, the effect is of a reduced magnitude, and we can conclude that democrats and republicans react to federal tax changes roughly in the same way.

Finally, we should note that the results obtained for the control variables are generally as 
expected. Richer populations demand more public goods, and so tax income more heavily (Inc and $I n c^{2}$ are statistically significant in model 4); richer governments return a highest amount of the transfers received to its citizens (the sign of Grant is negative but not significant). The size of the population results no significant in any of the models, but the density of population seems to impact negatively on income tax collection, showing perhaps higher cost due to the dispersion of the population, or higher possibilities to tax other bases in urban settings (e.g.: sales taxation). The states with a high proportion of population over 65 , and to a lesser extent, with a high proportion of population under 18 , use more intensively the income tax, maybe due to the higher demand of those two groups. Finally, with respect to the dummy variables that characterise the political environment of the state, only the proportion of senators that are democrat is significant, though the sign is negative in this case. 
Table III: Definition of the variables and statistical sources

\begin{tabular}{|c|c|c|}
\hline Variable & Definition & Statistical sources \\
\hline$t_{R}$ & $\begin{array}{l}\text { State effective average tax rate } \\
\text { as a percentage of personal income }\end{array}$ & $\begin{array}{l}\text { U.S. Bureau of the Census, State } \\
\text { Government Tax Collections by State }\end{array}$ \\
\hline$t_{F}$ & $\begin{array}{l}\text { Federal effective average tax rate } \\
\text { as a percentage of personal income }\end{array}$ & $\begin{array}{l}\text { U.S. Internal Revenue Service, Statistics of } \\
\text { Income Bulletin, quarterly }\end{array}$ \\
\hline$t_{L}$ & $\begin{array}{l}=0.05 \text { if some local governments } \\
\text { are entitled to use the income tax } \\
\text { base and } 0.2 \text { if the nominal local } \\
\text { tax rates are high }\end{array}$ & $\begin{array}{l}\text { A.C.I.R. Significant Features of Fiscal } \\
\text { Federalism, Vol. } 1 .\end{array}$ \\
\hline DRec & $\begin{array}{l}=1 \text { if the state personal income } \\
\text { tax allows for the deductibility of } \\
\text { federal income taxes }\end{array}$ & $\begin{array}{l}\text { A.C.I.R. Significant Features of Fiscal } \\
\text { Federalism, Vol. 1. }\end{array}$ \\
\hline Inc & $\begin{array}{l}\text { Personal income per capita in } 1986 \\
\text { Dollars }\end{array}$ & $\begin{array}{l}\text { Bureau of Economic Analysis, Regional } \\
\text { Accounts Data }\end{array}$ \\
\hline Grant & $\begin{array}{l}\text { Federal grants per capita in } 1986 \\
\text { Dollars }\end{array}$ & $\begin{array}{l}\text { U.S. Bureau of the Census, Federal } \\
\text { Expenditures by State for Fiscal Year, } \\
\text { annual }\end{array}$ \\
\hline Pop & State population & $\begin{array}{l}\text { U.S. Bureau of the Census, Current } \\
\text { Population Reports }\end{array}$ \\
\hline Den & State population per square Km & $\begin{array}{l}\text { U.S. Bureau of the Census, Current } \\
\text { Population Reports }\end{array}$ \\
\hline $\operatorname{Pop}(>65)$ & Proportion of population over 65 & $\begin{array}{l}\text { U.S. Bureau of the Census, Current } \\
\text { Population Reports }\end{array}$ \\
\hline $\operatorname{Pop}(<18)$ & Proportion of population under 18 & $\begin{array}{l}\text { U.S. Bureau of the Census, Current } \\
\text { Population Reports }\end{array}$ \\
\hline$D N C$ & $\begin{array}{l}=1 \text { if the state base does not conform } \\
\text { with any federal definition }\end{array}$ & $\begin{array}{l}\text { A.C.I.R. Significant Features of Fiscal } \\
\text { Federalism, Vol. 1. }\end{array}$ \\
\hline$D A G I$ & $=1$ if the state base is the federal AGI & $\begin{array}{l}\text { A.C.I.R. Significant Features of Fiscal } \\
\text { Federalism, Vol. 1. }\end{array}$ \\
\hline DTI & $=1$ if the state base is the federal TI & $\begin{array}{l}\text { A.C.I.R. Significant Features of Fiscal } \\
\text { Federalism, Vol. 1. }\end{array}$ \\
\hline$D T L$ & $\begin{array}{l}=1 \text { if the state applies a tax surcharge } \\
\text { over the federal tax liability }\end{array}$ & $\begin{array}{l}\text { A.C.I.R. Significant Features of Fiscal } \\
\text { Federalism, Vol. } 1 .\end{array}$ \\
\hline$D$-ExecD & $=1$ if the state governor is a Democrat & $\begin{array}{l}\text { Congressional Quaterly Inc., America Votes, } \\
\text { biennial }\end{array}$ \\
\hline UpperD & $\begin{array}{l}\text { Proportion of the state house } \\
\text { representives that are Democrats }\end{array}$ & $\begin{array}{l}\text { The Council of State Governments, State } \\
\text { Elective Officials and the Legislatures, } \\
\text { biennal }\end{array}$ \\
\hline LowerD & $\begin{array}{l}\text { Proportion of the state senators that } \\
\text { are Democrats }\end{array}$ & $\begin{array}{l}\text { The Council of State Governments, State } \\
\text { Elective Officials and the Legislatures, } \\
\text { biennal }\end{array}$ \\
\hline
\end{tabular}


Table IV: Summary statistics(1987-1996)

\begin{tabular}{lcccc}
\hline Variable & Mean & $\begin{array}{c}\text { Standard } \\
\text { deviation }\end{array}$ & Minimum & Maximum \\
\hline$t_{R}$ & 2,302 & 0,754 & 0,009 & 4,159 \\
$t_{F}$ & 9,464 & 0,935 & 7,608 & 13,661 \\
Drec & 0,231 & 0,422 & 0,000 & 1,000 \\
Inc & $18.935,891$ & $4.136,715$ & $10.301,000$ & $33.785,024$ \\
Grant & 665,150 & 221,741 & 326,020 & $2.153,305$ \\
Pop & 5.074 .283 & 5.345 .164 & 2.916 .025 & 10.162 .185 \\
Den & 68,649 & 88,488 & 2,097 & 393,591 \\
Pop(>65) & 12,705 & 1,547 & 8,210 & 15,954 \\
Pop(<18) & 26,384 & 2,276 & 22,610 & 38,178 \\
D-ExecD & 0,512 & 0,500 & 0,000 & 1,000 \\
UpperD & 73,391 & 75,065 & 43,478 & 97,059 \\
LowerD & 62,081 & 69,872 & 44,843 & 92,619 \\
\hline & & & & \\
\hline
\end{tabular}


Table V: Estimation results, dependent variable $t_{R}$,

$N^{\circ}$ Obs. $=410(N=41, T=10) ;$ Fixed effects estimation

\begin{tabular}{|c|c|c|c|c|}
\hline Variable & Model 1 & Model 2 & Model 3 & Model 4 \\
\hline$t_{F}$ & $\begin{array}{c}0.221 \\
(12.745)^{* * * *}\end{array}$ & $\begin{array}{c}0.243 \\
(16.790)^{* * * *}\end{array}$ & --.-- & $\begin{array}{c}0.184 \\
(14.102)^{* * * *}\end{array}$ \\
\hline$t_{F} \times D N C$ &.---- &.---- & $\begin{array}{c}0.235 \\
(10.415)^{* * *}\end{array}$ & --.-- \\
\hline$t_{F} \times D A G I$ &.---- &.---- & $\begin{array}{c}0.251 \\
(21.055)^{* * * *}\end{array}$ &.---- \\
\hline$t_{F} \times D T I$ &.---- &.---- & $\begin{array}{c}0.240 \\
(12.484)^{* * *}\end{array}$ &.---- \\
\hline$t_{F} \times D T L$ &.---- &.---- & $\begin{array}{c}0.228 \\
(8.870)^{* * * *}\end{array}$ &.---- \\
\hline$t_{L}$ &.---- & $\begin{array}{c}0.250 \\
(2.265)^{* *}\end{array}$ & $\begin{array}{c}0.240 \\
(2.451)^{* * * *}\end{array}$ & $\begin{array}{c}0.230 \\
(2.072)^{* *}\end{array}$ \\
\hline$t_{F} \times$ Drec &.---- & $\begin{array}{c}0.011 \\
(0.349)\end{array}$ & $\begin{array}{c}0.012 \\
(0.603)\end{array}$ & $\begin{array}{c}0.014 \\
(1.232)\end{array}$ \\
\hline $\bar{t}_{R} x\left(1-\bar{t}_{F}\right)$ &.---- & $\begin{array}{c}0.282 \\
(6.087)^{* * * *}\end{array}$ & $\begin{array}{c}0.299 \\
(6.245)^{* * *}\end{array}$ & $\begin{array}{c}0.302 \\
(7.156)^{* * * *}\end{array}$ \\
\hline$t_{F} \times$ DexecD &.--- &.---- &.---- & $\begin{array}{c}0.024 \\
(1.987)^{* *}\end{array}$ \\
\hline$t_{F} x$ UpperD &.---- &.---- &.---- & $\begin{array}{c}0.065 \\
(0.686)\end{array}$ \\
\hline$t_{F} \times$ LowerD &.---- &.---- &.---- & $\begin{array}{c}0.099 \\
(1.738)^{*}\end{array}$ \\
\hline $\operatorname{Inc} \quad\left(\begin{array}{lll} & \left.10^{-3}\right)\end{array}\right.$ & $\begin{array}{l}-0.851 \\
(-1.214)\end{array}$ & $\begin{array}{l}-0.902 \\
(-1.394)\end{array}$ & $\begin{array}{c}-0.906 \\
(-1.475)\end{array}$ & $\begin{array}{c}-1.034 \\
(-2.023)^{* *}\end{array}$ \\
\hline $\operatorname{Inc} c^{2} \quad\left(\times 10^{-3}\right)$ & $\begin{array}{c}0.041 \\
(1.541)\end{array}$ & $\begin{array}{c}0.030 \\
(1.603)\end{array}$ & $\begin{array}{c}0.032 \\
(1.724)^{*}\end{array}$ & $\begin{array}{c}0.040 \\
(2.652)^{* * *}\end{array}$ \\
\hline Grant $\left(\times 10^{-3}\right)$ & $\begin{array}{c}-0.185 \\
(-1.014)\end{array}$ & $\begin{array}{c}-0.257 \\
(-1.284)\end{array}$ & $\begin{array}{c}-0.176 \\
(-1.452)\end{array}$ & $\begin{array}{c}-0.284 \\
(-1.577)\end{array}$ \\
\hline Pop $\quad\left(\times 10^{-5}\right)$ & $\begin{array}{c}-0.294 \\
(-1.218)\end{array}$ & $\begin{array}{c}-0.298 \\
(-1.223)\end{array}$ & $\begin{array}{c}-0.282 \\
(-1.155)\end{array}$ & $\begin{array}{c}-0.338 \\
(-1.409)\end{array}$ \\
\hline $\operatorname{Pop}^{2}\left(x 10^{-10}\right)$ & $\begin{array}{c}0.641 \\
(1.247)\end{array}$ & $\begin{array}{c}0.509 \\
(1.341)\end{array}$ & $\begin{array}{c}0.503 \\
(1.329)\end{array}$ & $\begin{array}{c}0.519 \\
(1.397)\end{array}$ \\
\hline Den & $\begin{array}{c}-0.359 \\
(2.141)^{* * *}\end{array}$ & $\begin{array}{c}-0.354 \\
(2.038)^{* *}\end{array}$ & $\begin{array}{c}-0.361 \\
(2.122)^{* *}\end{array}$ & $\begin{array}{c}-0.383 \\
(-2.272)^{* *}\end{array}$ \\
\hline $\operatorname{Pop}(>65)$ & $\begin{array}{c}0.201 \\
(2.221)^{* *}\end{array}$ & $\begin{array}{c}0.226 \\
(2.037)^{* * *}\end{array}$ & $\begin{array}{c}0.216 \\
(2.051)^{* *}\end{array}$ & $\begin{array}{c}0.175 \\
(2.274)^{* * *}\end{array}$ \\
\hline $\operatorname{Pop}(<18)$ & $\begin{array}{c}0.028 \\
(1.741)^{*}\end{array}$ & $\begin{array}{c}0.043 \\
(1.889)^{*}\end{array}$ & $\begin{array}{c}0.042 \\
(1.902)^{*}\end{array}$ & $\begin{array}{c}0.055 \\
(1.871)^{*}\end{array}$ \\
\hline DexecD & $\begin{array}{c}0.002 \\
(0.048)\end{array}$ & $\begin{array}{c}0.001 \\
(0.186)\end{array}$ & $\begin{array}{c}0.001 \\
(0.338)\end{array}$ & $\begin{array}{c}0.002 \\
(0.695)\end{array}$ \\
\hline UpperD & $\begin{array}{c}-0.005 \\
(-0.101)\end{array}$ & $\begin{array}{c}-0.005 \\
(-0.133)\end{array}$ & $\begin{array}{c}-0.004 \\
(-0.117)\end{array}$ & $\begin{array}{c}0.004 \\
(0.587)\end{array}$ \\
\hline LowerD & $\begin{array}{c}-0.029 \\
(-1.974)^{* *}\end{array}$ & $\begin{array}{c}-0.044 \\
(-2.048)^{* *}\end{array}$ & $\begin{array}{c}-0.002 \\
(-1.079)\end{array}$ & ${ }^{-0.001}$ \\
\hline $\bar{R}^{2}$ & 0.868 & 0.880 & 0.880 & 0.902 \\
\hline B.P. & 0.054 & 0.125 & 0.192 & 0.087 \\
\hline $\begin{array}{l}D . W . \\
F\left(C,{ }^{\prime}\right.\end{array}$ & 1.985 & 1.987 & 2.102 & 2.004 \\
\hline $\begin{array}{l}F\left(C v s . C_{i}\right) \\
\chi^{2}(\text { Hausman test })\end{array}$ & $\begin{array}{l}110.21^{* * *} \\
68.54^{* * *}\end{array}$ & $\begin{array}{l}113.87^{* * *} \\
77.812^{* * * *}\end{array}$ & $\begin{array}{l}110.49^{*} \\
88.722^{* * * * *}\end{array}$ & $\begin{array}{l}100.55^{* * *} \\
99.736^{* * * *}\end{array}$ \\
\hline
\end{tabular}




\section{Conclusions}

In this paper, our main aim was to test empirically the relevance of the vertical tax externality for personal income taxation. The evidence we have found seems to confirm that hypothesis. The theoretical model developed in section 2 predicted a positive reaction of each level of government to changes in the effective tax rates of the other. The model also found that in the presence of Tax deductibility and Reciprocal tax deductibility the reaction were more pronounced. The simulations performed in section 2.4, calibrated to reflect the current U.S. situation, have allowed us to have a guess about the magnitude of the response in the different cases. Finally, the results of the empirical analysis of section 3 have permitted us to confirm such results. We have found in our econometric analysis that one point increase in the federal net effective tax rate is followed by an increase of approximately 0,25 points in the state tax rate, a response very similar to the reaction found previously in the simulations (for a tax base elasticity of 0,75$)$. We think this magnitude is consistent the effects of the vertical tax externality and the tax deductibility working simultaneously. Remember that the magnitude of the reaction obtained in the simulations for the Vertical tax externality case was around 0,10 points (for the same value of the elasticity). We have computed that if there were no vertical tax externality but only the tax deductibility, the simulated reaction would be of 0,09 points. However, to obtain a definitive conclusion of the relative importance of both effects we would have to compare a real situation without tax deductibility with the results of the U.S. case. At the moment, we are developing an empirical test for the Canadian case that would allow us to perform this comparison, and so to improve our present conclusions.

If our guesses about the empirical relevance of the vertical tax externality are true, useful political economy insights for the Spanish case can be derived. As commented in the introduction, the Spanish regions have recently achieved a relatively important power on the personal income tax. The critics of this reform have only emphasised the negative effects of potential tax competition among regions. However, as we have shown, the vertical tax externality can provoke distortions on tax decisions that could be equally harmful. In any case, the potentially negative effects of the vertical tax externalities should be balanced with the positive effect of greater fiscal responsibility at the regional level of government. 


\section{References}

Alesina, A., Rosenthal, H. (1995): Partisan Politics, Divided Government, and the Economy, Cambridge University Press.

ARNOTT, R., GRIESON, R. (1981): „Optimal tax policy for a state or local government“, Journal of Urban Economics, Vol.9, No.1, 23-48.

BARRO, R., SAHASAKUL, CH. (1986): „Average marginal tax rates from social security and the individual income tax“, Journal of Business, 59, 555-66.

BESLEY, T.J., AND CASE, A. (1995,a): "Incumbent Behavior: Vote Seeking, Tax Setting and Yardstick Competition", American Economic Review, Vol. 85, No. 1, 25-45.

- (1995,b): „Does Electoral Accountability Affect Economic Policy Choices? Evidence from Gubernatorial Term Limits“, Quarterly Journal of Economics, Vol. CX, No. 3, 769-98.

Besley, T.J., AND Rosen, H.S. (1997): „Vertical Externalities in Tax Setting: Evidence from Gasoline and Cigarettes“, Center For Economic Policy Studies, Working Paper No. 46, Princeton University.

BOADWAY, R., AND KEEN, M (1996): „Efficiency and the Optimal Direction of Federal-State Transfers“, International Tax and Public Finance, Vol. 3, No. 2, 137-55.

BOADWAY, R., MARChAND, M., AND VigneAult, M. (1997): „The Consequences of Overlapping Tax Bases for Redistribution and Public Spending in a Federation“, Institute for Economic Research, Working Paper No.963, Queen's University (On-line version: http://qed.econ.queensu.ca/ pub/papers/ abstracts/download.html\#963).

BORDignON, M., MANASSE, P., TABELlini, G. (1996): „Optimal regional redistribution under asymmetric information“, IGIER, Working Paper No. 93, Universita' Bocconi ( On-line version: $\mathrm{ftp} / / / \mathrm{ftp}$. igier.uni-bocconi.it/wp/1996/93.pdf)

BREAK, G.F. (1980): „Tax Principles in a Federal System“, in Aaron, H.J., and Boskin, M.J.: The Economics of Taxation, The Brookings Institution.

CASE, A.C. (1993): „Interstate tax competition after TRA86“, Journal of Policy Analysis and Management, Vol.12, No.1, 136-48..

-, HINES, J.R., AND ROSEN, H.S. (1993): „Budget spillovers and fiscal policy interdependence“, Journal of Public Economics, Vol. 52, 285-307.

DAHLBY, B.-, (1997): „Vertical Fiscal Externalities and the Under-Provision of Prodctivity-Enhancing Activities by State Governments“, Institute for Public Economics, Research Paper 97-1, University of Alberta (On-line version: http:// www.ualberta.ca/ econweb/IPE/ pubs/ vertical.pdf).

DIXIT, A.K., AND LONDREGAN, J. (1998): „Fiscal federalism and redistributive politics“, Journal of Public Economics, Vol. 68, No.2,153-180.

FEENBERG, D.R., and Rosen, H. (1986,a): ,The interaction of State and federal Tax systems: the impact of state and local deductibility“, American Economic Review, 76, 2, 126-31.

- (1986,b). „State personal income and sale taxes: 1977-1983“, Rosen, H. (ed.) Studies in State and Local Government Finance, University of Chicago Press.

FEENBERG, D.R., AND Rosen, H. (1987): „Tax structure and public sector growth“, Journal of Public Economics, Vol. 32, 185-201.

FELDSTEIN, M. (1995,a): „Behavioral Responses to Tax rates: Evidence from TRA86“, NBER Working Paper No. 5000.

FELDSTEIN, M. (1995,b): „Tax Avoidance and the deadweight loss of the income tax“, NBER Working Paper No. 5055.

-, AND METCALF, D. (1987): „The effect of federal tax deductibility on state and local taxes and spending“, Journal of Political Economy, No. 95, 710-36.

FISHER, R.C.(1996): State and Local Public Finance, Ch. 16, $2^{\text {nd }}$. Edition, Irwin.

FLOWERS, M.R. (1996): „Shared Tax Sources in a Leviathan Model of Federalism“, Public Finance Quarterly, 16, 67-77. 
GADE, M. AND ADKINS, L. (1990): „Tax exporting and State revenue structure“, National Tax Journal, Vol. 43, 39-52.

GOLD, S.D. (1991): „Changes in State Government Finances in the 1980s“, National Tax Journal, Vol. XLIV, No. 1, 1-19.

GORDON, R.H. (1983): „An Optimal Taxation Approach to Fiscal Federalism“, Quarterly Journal of Economics, 98, 567-86.

GOUVEIA, M., STRAUSS, R.P. (1994): „Effective federal individual income tax functions: An exploratory analysis“, National Tax Journal, Vol. 47, No.2, 317-39.

GREENE, K.V., AND HAWLEY, B.K. (1991): „Personal Income taxes, elasticities and fiscal illusion“, Public Choice, Vol. 72, 101-9.

HAUSMAN, J. (1978): „Specification tests in econometrics“, Econometrica, 46, 1251-71.

HAUSMAN, J., AND TAYLOR, W. (1987): „Panel data and unobservable individual effects“, Econometrica, 49, 1377-95.

HetTich, W., WinER, S. (1984): „A positive model of tax structure“, Journal of Public Economics, Vol. 24, 67-87.

HOLTZ-EAKIN, D. (1986): „Unobserved tastes and the determination of municipal services“, National Tax Journal, Vol. 39, 527-32.

HoltZ-EAKIN, D., AND RoSEN, H (1987): „Tax deductibility and municipal budget structure“, in Rosen, H. (ed.) Fiscal Federalism: Quantitative Studies, University of Chicago Press.

HSIAO, C. (1986): Analysis of Panel data, Cambridge University Press .

JoHnsON, W.R. (1988): „Income Redistribution in a Federal System“, American Economic Review, Vol. 78, 570-73.

KeEN, M. (1997): „Vertical Tax Externalities in the Theory of Fiscal Federalism“, Working Paper of the International Monetary Fund, Fiscal Affairs Department, 173 (On-line version: http://www.imf.org/external/pubs/ft/wp/wp97173.pdf).

KENYON, D. (1986): „Federal income tax deductibility of state and local taxes“, in Federal-State-Local relations, Technical Papers, Vol. 1, Department of the Treasury.

LADD, H. (1993): „State Responses to the TRA86 Revenue Windfalls: A New Test of the Flypaper Effect", Journal of Policy Analysis and Management, Vol. 12, No. 1, 82-103.

LANDON, S., AND RYAN, D.L.: ,The political cost of taxes and government spending“, Canadian Journal of Economics, Vol. 30. No.1, 85-111.

LINDSEY, L. (1987): „Federal deductibility of state and local taxes: a test of public choice by representative government", in Rosen, H. (ed.) Fiscal Federalism: Quantitative Studies, University of Chicago Press.

MinTZ, J., TUlKENS, H. (1986): „Commodity Tax Competition Between member States of a Federation: Equilibrium and Efficiency“, Journal of Public Economics, Vol. 29, 133-72.

MulLEN, J.K., WilliaMS, M. (1994): „Marginal tax rates and state economic growth“, Regional Science and Urban Economics, 24, 687-705.

MUNDLAK, Y. (1978): „On the pooling of time series and cross-section data“, Econometrica, 46, 69-85.

MusGraVE, R. (1983): „Who should tax, where and what?“, in McLure, C.E., (ed.): Tax assignment in federal countries, Australian National University Press.

PEDRÓS, A. (1998): „Comentarios en relación con el Informe para el Estudio y Propuesta de medidas para la reforma del IRPF“", mimeo, Universitat de Barcelona.

PELTZMAN, S. (1990): „How efficient is the voting market“, Journal of Law and Economics, 33, 27-63.

RYE, R.C., SEARLE, B. (1997): „The Federal Transfer System in Australia“, in Ahmad, E. (ed.) Financing Decentralized Expenditure: An International Comparison of Grants, Edward Elgar.

RUIZ-HUERTA, J., LÓPEZ-LABORDA, J. (1997): „Catorce preguntas sobre el nuevo sistema de financiación autonómica“, 581-615, in Informe Comunidades Autónomas 1996, Vol. 1, Instituto de Derecho Público. 
SATO, M. (1997): „A Second Best Theory of a Fiscal Federal System“, Queen’s Institute for Economic Research, Working Paper No.943, Queen's University (On-line version: http://qed.econ.queensu.ca/pub/papers/abstracts/download.html\#943).

SEATER, J. (1985): „On the construction of marginal federal personal and social security tax rates in the US“, Journal of Monetary Economics, 15, 121-35.

STEPHENSON, S.C., AND HEwET, R.S. (1984): „Strategies for States in Fiscal Competition“, National tax Journal, Vol. 38, 219-226.

TANNENWALD, R. (1991): „The US Tax Reform Act 1986 and State Competitiveness“, 177-204, in Kenyon, D.A., and Kincaid, J. (eds.): Competition among States and Local governments, The Urban Institute Press.

TANZI, V. (1995): „Fiscal Federalism and decentralization: A review of some efficiency and macroeconomic aspects“, World Bank Economic Review (Annual World Bank Conference on Development Economics), 295-316.

WAGONER, C.B. (1995): „Local Fiscal Competition: An Intraregional Perspective“, Public Finance Quarterly, Vol. 23, No. 1, 95-114.

WREDE, M. (1996): „, Vertical and Horizontal Tax Competition: Will Uncoordinated Leviathans end up on the Wrong Side of the Laffer Curve?“", Finanz. Archiv, Band 53, Heft 3, 461-79. 